\title{
A Bibliometric Analysis in the Field of Pediatric Anesthesia and Turkey's Contribution to Research
}

\author{
Pediatrik Anestezi Alanındaki Yayınların \\ Bibliyometrik Analizi ve Türkiye Kaynaklı \\ Yayınların Bu Alana Katkısı
}

\section{ABSTRACT}

Objective: Bibliometric analysis can be used to assess the contributions of scholars, institutions, countries by examining the materials published in a certain discipline. The objective of this study is to make a bibliometric analysis in the field of pediatric anesthesia and to examine Turkey's contribution to research in this field.

Methods: I used the search engine of the Web of Science (WoS), and included all types of contributions (original articles, reviews, letters, editorials, etc.) in the bibliometric analysis. I scanned Science Citation Index Expanded (SCIE) and Emerging Sources Citation Index (ESCI) as they were the most relevant indexes for my study. Statistical analyses were performed by using SPSS 22. I used a binomial test to make a comparison between Turkey and other countries in terms of research output, and academic performance.

Results: Pediatric Anesthesia is the only journal that positions itself in WoS categories of both "pediatrics" and "anesthesia". A total of 5,791 citations were found in this particular journal of which 227 were from Turkey. In addition to this journal, 2,096 published materials were found in 433 different sources. Turkish authors have made only 61 contributions to these journals. Hacettepe University, Istanbul University, and Baskent University are the predominant institutions from Turkey accounting for a total of 80 published materials.

Conclusion: The findings of this bibliometric analysis not only showed the contribution of Turkish authors to the field of pediatric anesthesia but also revealed the areas of improvement for their future research. The study also showed a list of journals that publish articles in the area of pediatric anesthesia.

Keywords: Pediatrics, anesthesia, bibliometric analysis, Turkey

öz

Amaç: Bibliyometrik analiz yöntemi, belirli bir disiplinde yayınlanan materyalleri inceleyerek akademisyenlerin, kurumların ve ülkelerin katkılarını değerlendirmek için kullanılabilir. Bu çalışmanın amacı pediatrik anestezi alanında bibliyometrik bir analiz yapmak ve Türkiye kaynaklı yayınların bu alana katkısını incelemektir.

Yöntem: Web of Science'ın (WoS) arama motorunu kullanarak, her türlü bilimsel yazı çalışmaya dahil edildi (orijinal makaleler, incelemeler, mektuplar, başyazılar vb.). Araştırma için en alakalı indeksler olan Science Citation Index Expanded (SCIE) ve Emerging Sources Citation Index'i (ESCI) çalışmaya dahil edildi. Istatistiksel analizler SPSS 22 kullanılarak yapıldı. Türkiye ile diğer ülkelerin akademik çıktı performanslarını karşılaştırmak için Binom testi kullanıldı.

Bulgular: 'Pediatrik Anestezi' dergisi WoS kategorilerinde kendisini hem "pediatri" hem de "anestezi" olarak konumlandıran tek dergiydi. Bu dergide 227'si Türkiye'den olmak üzere 5,791 kayıt bulundu. Bu dergiye ek olarak, 433 farklı dergide 2,096 bilimsel yayın bulundu. Bu dergilerde Türk yazarların katkısı sadece 61 yayın ile sınırlı idi. Hacettepe Üniversitesi, İstanbul Üniversitesi ve Başkent Üniversitesi, bu alanda toplam 80 yayın sayesinde Türkiye'de en önde gelen kurumlardır.

Sonuç: Bu bibliyometrik analizin bulguları, Türk yazarların pediatrik anestezi alanına katkılarını göstermesinin yanı sıra, gelecekteki çalışmalar için iyileştirme alanlarını da ortaya koydu. Çalışma ayrıca pediatrik anestezi alanında yayın yapan dergilerin bir listesini de sunmaktadır.

Anahtar kelimeler: Pediatri, anestezi, bibliyometrik analiz, Türkiye
Received: 09.02.2021

Accepted: 15.02 .2021

Published Online: 03.08.2021

Cite as: Ayvat P. A bibliometric analysis in the field of pediatric anesthesia and Turkey's contribution to research. İzmir Dr. Behçet Uz Çocuk Hast. Dergisi. 2021;11(2):159-66

Pınar Ayvat

Izmir Demokrasi Üniversitesi Tıp Fakültesi, Anestezi ve Reanimasyon Anabilim Dalı, İzmir, Türkiye

- pinar.ayvat@idu.edu.tr ORCID: 0000-0002-9941-3109 


\section{INTRODUCTION}

As has been happening in other branches of medicine, we have been observing new subdisciplines in the field of anesthesia and reanimation in recent years. Pediatric anesthesia, neuroanesthesia, cardiothoracic anesthesia, and obstetric anesthesia are some examples of these subdisciplines. This situation caused the academic journals to position themselves according to the needs of new segments of readers in different subdisciplines. The number of articles published in the field of anesthesia around the world has been increasing. One can evaluate and assess the contributions of scholars, institutions or countries, by examining the articles published in a certain discipline. Bibliometric analysis is a method used for this purpose. Thus, we can make comparisons among countries gain information about the contributions of scholars to scientific publications, compare the contributions of state and private institutions in a particular discipline, and examine co-authorship trends.

Unlike intensive care and algology, pediatric anesthesia is not accepted as a subdiscipline of anesthesia in Turkey. However, pediatric surgery and the care of pediatric patients require a different level of know-how. Because of this accumulated amount of expertise, scholars from all around the world have been producing large amounts of academic output. The number of articles on specific disciplines such as pediatric anesthesia is indicative of publication activity in this respective field ${ }^{(1)}$. This study aims to make a bibliometric analysis of the scientific literature published in the field of pediatric anesthesia and then to determine Turkey's relevant position. The main research questions (RQ) are as follows:

RQ1: How many journals are there in the Web of Science (WoS) collection that position themselves in the WoS categories of "pediatrics" and "anesthesiology" at the same time?

RQ2: How many published materials deserve global scientific value in "pediatrics" and "anesthesiology" categories, and how many of them are produced in Turkey?

RQ3: Are there other journals that publish articles in the field of pediatric anesthesiology even though those journals do not position themselves in WoS categories of "pediatrics" and "anesthesiology" simultaneously. If the answer is yes, what are those journals, and how many published articles are from Turkey, and other countries?

RQ4: In pediatric anesthesiology, what are the main Turkish institutions that contribute to the literature?

RQ5: What is the average cited reference count of published articles from Turkey compared to globally published articles?

RQ6: How many authors contributed to the published materials from Turkey, compared to published materials worldwide?

\section{MATERIAL and METHODS}

I conducted all searches in the "Advanced Search" section of Clarivate Analytics' Web of Science (WoS) Core Collection database on $24^{\text {th }}$ October 2020. I checked the "All years (1975-2020)" option for the timespan and I looked for the records in citation indexes of SCIE (Science Citation Index Expanded) and $\mathrm{ESCl}$ (Emerging Sources Citation Index). I excluded citation indexes of $\mathrm{SSCl}, \mathrm{A} \& \mathrm{HCl}, \mathrm{CPCl}-\mathrm{S}, \mathrm{CPCl}-\mathrm{SSH}$, $\mathrm{BKCl}-\mathrm{S}, \mathrm{BKCl}-\mathrm{SSH}$ from my search as they were not relevant for my study. To find the currently published journals on pediatric anesthesia, I checked WoS categories that simultaneously include "Pediatrics" and "Anesthesiology". Therefore I used the search string: $\mathrm{WC}=$ (Pediatrics AND Anesthesiology). 1 looked for records from Turkey in these categories by using the searchstring: $\mathrm{WC}=$ (Pediatrics AND Anesthesiology) AND CU=Turkey. In the address sections of the citations, if there was at least one author from Turkey, that record was accepted as a publication from Turkey.

In addition to this, I made another search with the string: (TS=" $P^{*}$ diatric An*esthesi*" OR $\mathrm{Tl}=$ "P*diatric An*esthesi*" OR $\mathrm{AB}=$ " $\mathrm{P} *$ diatric An*esthesi*" OR AK="P*diatric An*esthesi*") NOT (SO=PEDIATRIC ANESTHESIA OR SO=(PAEDIATRIC ANAESTHESIA)). With this, I looked for records that included variations of the words pediatric, paediatric, 
anesthesia, anaesthesia, anesthesiology, anaesthesiology, anesthesiolog, anaesthesiolog, etc. in the titles, abstracts, or keywords of the publications in journals that do not position themselves in WoS categories of "Pediatrics" and "Anesthesiology" together. In order to refine this search for Turkey only, I used the search string:

((TS="P*diatric An*esthesi*" OR $\mathrm{Tl}=$ " $\mathrm{P} *$ diatric An*esthesi*" OR $A B=" P *$ diatric An*esthesi*" OR $A K=" P *$ diatric An*esthesi*") NOT (SO=PEDIATRIC ANESTHESIA OR SO=(PAEDIATRIC ANAESTHESIA))) AND CU $=$ Turkey.

Statistical analyses were performed by using SPSS 22. I used a binomial test to make a comparison between academic output performance of Turkey and other countries. Ethical approval for this study was obtained from Ethics Committee of Izmir Democracy University Buca Seyfi Demirsoy Education and Research Hospital.

\section{RESULTS}

When I scanned the journals that position themselves in the WoS categories of "pediatrics" and "anesthesiology" simultaneously, I realized that all records were from two journals: "Pediatric Anesthesia" and "Paediatric Anaesthesia". These two journals are actually the same journal as their ISSN is the same (1155-5645). Apparently, the editors changed the title of the journal from "Paediatric Anaesthesia" to "Pediatric Anesthesia" in March 2004 after they obtained an eISSN, which shows that the journal also started to be published online after that particular time. This periodical is from England and its first issue appeared in 1995. Right before it changed its title and started publishing online in 2004, its impact factor (IF) for 2003 was 0.98.

The journal's IF was 2.04 in the year 2018. The journal's ISSN/eISSN is 1155-5645/1460-9592 and it currently publishes 12 issues per year.

Between 1995-2020, there were 5,791 records in this journal, 3,110 of which were articles and 498 were reviews. The rest were letters, notes, editorials, etc. When I checked the records in this journal that were from Turkey, the result was 227 records. Turkish authors started to publish their articles in this journal as early as 1997 with the $7^{\text {th }}$ volume and $5^{\text {th }}$ issue. Articles made up 119 of these records, one of them was a review article and 107 of them were letters.

Obviously, "Pediatric Anesthesia" is the only journal in WoS collection that positions itself in the "Web of Science Categories" of pediatrics and anesthesiology at the same time. I suspected that it was unlikely that this journal was the only journal that published articles about pediatric anesthesia. There should have been some other journals of anesthesia that could accept and publish articles, reviews, letters about pediatric anesthesia, pediatrics, or in some other disciplines of medicine. When I looked for records that included variations of the words pediatric anesthesia/anesthesiology etc. I got 2.096 results. None of these results included published materials in the journal of "Pediatric Anesthesia", so I did not include this specific journal in my bibiliometric analysis. These 2.096 records were published in 433 different sources. I analyzed the first 20 sources, namely $54 \%$ ( $n: 1.130)$ of all records (Table I). Research domains of all these journals included "Anesthesiology". In fact, the titles of these 20 journals included the word "anesthesia" or" anesthesiology". There were 6 journals from the USA, 4 from England, and 3 from Italy. Sixteen of them are published in English whereas 3 of them accept multiple languages and one is released in German. Eighteen of them are indexed in SCIE and only 2 are indexed in $\mathrm{ESCl}$. The average IF in 2008 for these journals was 2.72. Eight of them were in Q1 whereas 7, 2, and 3 of them were in Q2, Q3, and Q4 quartiles, respectively.

When I checked the records in the 433 different journals mentioned above, 61 records were from Turkey including 49 articles and 12 letters. The earliest work was from 2007. Turkish authors had their works published in 36 different journals.

I looked for 10 institutions from Turkey that contributed most to the literature both in the journal of "Pediatric Anesthesia" and in other journals (Table II). Except for Baskent University, Yeditepe University, and Bezmialem Vakif University, all of the institutions were state universities. Hacettepe University, Istanbul 
Table 1. Top 20 journals according to the number of published materials (except "Pediatric Anesthesia").

\begin{tabular}{|c|c|c|c|c|c|c|c|c|c|}
\hline Order & Journals & $\begin{array}{l}\text { Records } \\
\text { (Total) }\end{array}$ & $\begin{array}{l}\text { Records } \\
\text { (Turkey) }\end{array}$ & $\begin{array}{l}\text { Country of } \\
\text { Publication }\end{array}$ & ISSN/e-ISSN & $\begin{array}{l}\text { First Pub. } \\
\quad \text { Year }\end{array}$ & $\begin{array}{l}\text { Issues/ } \\
\text { year }\end{array}$ & $\begin{array}{l}2018 \\
\text { IF }\end{array}$ & Quarter \\
\hline 1 & Anesthesia and Analgesia & 184 & 0 & USA & 0003-2999 & 1921 & 12 & 3.5 & Q1 \\
\hline 3 & Anaesthesia & 100 & 0 & England & $0003-2409 / 1365-2044$ & 1946 & 12 & 5.9 & Q1 \\
\hline 4 & Anaesthesist & 89 & 0 & Germany & $0003-2417 / 1432-055 X$ & 1952 & 12 & 0.9 & Q3 \\
\hline 5 & Current Opinion in Anesthesiology & 84 & 0 & USA & $0952-7907 / 1473-6500$ & 1988 & 6 & 2.1 & Q1 \\
\hline 8 & Journal of Clinical Anesthesia & 62 & 12 & Holland & $0952-8180 / 1873-4529$ & 1989 & 8 & 3.5 & Q2 \\
\hline 9 & $\begin{array}{l}\text { Annales Francaises d Anesthesie et de } \\
\text { Reanimation }\end{array}$ & 61 & 0 & France & 0373-8701 & 2015 & 6 & 2.7 & Q4 \\
\hline 10 & Journal of Neurosurgical Anesthesiology & 36 & 0 & USA & 0898-4921/1537-1921 & 1989 & 4 & 3.0 & Q2 \\
\hline 11 & Anasthesiologie \& Intensivmedizin & 34 & 0 & Germany & 0170-5334/1439-0256 & 1960 & 12 & 0.7 & Q3 \\
\hline 12 & Indian Journal of Anaesthesia & 31 & 0 & India & 0019-5049/0976-2817 & 1953 & 12 & 1.3 & Q2 \\
\hline 16 & Anaesthesia and Intensive Care Medicine & 27 & 0 & England & $1472-0299 / 1878-7584$ & 2003 & 12 & 0.5 & Q4 \\
\hline 17 & Anaesthesia and Intensive Care & 26 & 0 & Australia & $0310-057 X / 1448-0271$ & 1972 & 6 & 1.4 & Q2 \\
\hline 18 & Canadian Journal of Anaesthesia & 25 & 0 & Canada & 0832-610X/1496-8975 & 1908 & 12 & 3.4 & Q1 \\
\hline 19 & Minerva Anestesiologica & 22 & 1 & Italy & 0375-9393/1827-1596 & 1953 & 12 & 2.8 & Q2 \\
\hline \multirow[t]{2}{*}{20} & $\begin{array}{l}\text { Journal of Cardiothoracic and Vascular } \\
\text { Anesthesia }\end{array}$ & 22 & 0 & USA & $1053-0770 / 1532-8422$ & 1986 & 10 & 1.9 & Q2 \\
\hline & TOTAL & 1.130 & 18 & & & & & & \\
\hline
\end{tabular}

Table 2. Ten institutions from Turkey that contributed most to the pediatric anesthesia literature.

\begin{tabular}{|c|c|c|c|c|c|}
\hline \multicolumn{3}{|c|}{ Number of published materials in "Pediatric Anesthesia" } & \multicolumn{3}{|c|}{$\begin{array}{l}\text { Number of published materials in journals other than "Pediatric } \\
\text { Anesthesia" }\end{array}$} \\
\hline Order & Institution & Records & Order & Institution & Records \\
\hline 1 & Hacettepe University & 29 & 1 & Kocaeli University & 9 \\
\hline 2 & Istanbul University & 25 & 2 & Cukurova University & 6 \\
\hline 3 & Baskent University & 20 & 3 & Adnan Menderes University & 4 \\
\hline 4 & Selcuk University & 14 & 4 & Yeditepe University & 4 \\
\hline 5 & Gazi University & 12 & 5 & Baskent University & 3 \\
\hline 6 & Çukurova University & 9 & 6 & Istanbul University & 3 \\
\hline 7 & Erciyes University & 9 & 7 & Adıyaman University & 2 \\
\hline 8 & Kocaeli University & 9 & 8 & Ataturk University & 2 \\
\hline 9 & Ege University & 8 & 9 & Bezmialem Vakıf University & 2 \\
\hline 10 & Ondokuz Mayıs University & 8 & 10 & Dokuz Eylul University & 2 \\
\hline
\end{tabular}

University, and Baskent University dominated the other institutions with a total of 80 published materials. That fact is not surprising as Hacettepe University, and Istanbul University are among the oldest medical faculties in Ankara and Istanbul, respectively; and Baskent University is the oldest private university that has a medical school in Ankara.

When I examined the materials published in
"Pediatric Anesthesia" and other materials published in other journals that include all variations of the words "pediatric anesthesia" in their titles, abstracts, or keywords, the total number of records was 7.887 including 288 records from Turkey. The earliest publication was from 1980 and the latest from 2020. The cumulative number of published materials in each decade between the years 1980 and 2020 were 108; 1.078; 3.127 and 3.574, respectively. In Table III, 
Table 3. Comparative information between Turkey and other countries regarding the published materials.

\begin{tabular}{|c|c|c|c|c|c|}
\hline & Turkey & $\%$ & Other countries ( $n$ ) & $\%$ & $\mathbf{P}$ \\
\hline Number of articles & 168 & 58.3 & 4.045 & 53.2 & 0.68 \\
\hline Number of reviews & 1 & 0.3 & 717 & 9.4 & $0.04 *$ \\
\hline Number of letters & 107 & 37.2 & 1.750 & 23.0 & $0.01^{*}$ \\
\hline Number of other materials & 12 & 4.2 & 1.087 & 14.3 & $0.01^{*}$ \\
\hline Total & 288 & 100.0 & 7.599 & 100.0 & \\
\hline Number of cited references & 4,374 & & 142.864 & & \\
\hline Average number of cited references & 15.2 & & 20.1 & & \\
\hline Average number of pages & 4.4 & & 5.3 & & \\
\hline Average number of authors & 4.5 & & 3.82 & & \\
\hline Published materials with 1 or 2 authors & 47 & 16.3 & 2.686 & 35.3 & $0.00 *$ \\
\hline Published materials with 3 or more authors & 241 & 83.7 & 4.913 & 64.7 & $0.03^{*}$ \\
\hline Total & 288 & 100.0 & 7.599 & 100.0 & \\
\hline Number of published materials between 2016-2020 & 52 & 18.1 & 1.782 & 23.5 & 0.45 \\
\hline Number of published materials between $1980-2015$ & 236 & 81.9 & 5.817 & 76.5 & 0.74 \\
\hline Total & 288 & 100.0 & 7.599 & 100.0 & \\
\hline
\end{tabular}

* Statistically significant $(P<0.05)$.

you can find comparative information between Turkey and other countries regarding the number of published materials, the number of cited references, authors, pages over a specified period of time. Published materials of Turkish authors were cited 15.2 times on average, whereas materials from other countries were cited 20.1 times. The average number of authors per published material was 4.50 for records from Turkey, but this figure was 3.82 for other countries. The average number of pages of articles only was 5.8 for Turkish authors and 6.4 for the authors from other countries. The number of published materials in the last five years from Turkey was 52 which made up $18.1 \%$ of the total records from Turkey, whereas it was 1.782 comprising $23.5 \%$ of the records from other countries.

\section{DISCUSSION}

This bibliometric analysis has yielded important results for researchers in the field of pediatric anesthesia with an emphasis on Turkish scholars' position in the literature. The major journals that publish articles on pediatric anesthesiology, the number of materials published in those journals, average number of cited references, the number of authors per published material, and Turkish researchers' role in the literature have been demonstrated in this bibliometric analysis. With bibliometric analyses, some researchers looked for answers to various research questions. For example, one study identified the top-cited published materials and the most influential journals in the field of anesthesia; and the researchers also identified the institutions and researchers that produce the highest number of academic output (2). Xie et al. ${ }^{(3)}$ studied China's contribution to researches in the field of anesthesiology between 2005-2014 by retrieving data from the PubMed and WoS databases. They analyzed the total number of articles, type of published materials, number of citations, and citation rates of 6 different countries in 29 journals of anesthesiology. Tripathi et al. (4) compiled a comprehensive list of the most-cited articles in anesthesia between 1945 and 2008 by using the WoS database which was called "ISI Web of Knowledge" at the time of their research. To find the articles related to anesthesiology, the researchers used a similar search string as in my study, which makes use of the "*" symbol as a wildcard to retrieve all possible variations of the word anesthesia (4). Bould et al. (5) identified the published materials attributed to each country in the anesthesia literature. They also grouped the articles by the 
gross national income of a particular country to look for a relationship between economic productivity and academic output. They concluded that $89.2 \%$ of the articles were published by contributors from high-income countries.

In recent years, the number of children undergoing operative procedures has increased and many specialists have been devoting their expertise to provide anesthesia for children ${ }^{(1)}$. Because of this dedication, the number of published scientific materials on pediatric anesthesia also increased. Indeed, in this study, I found that $45.3 \%$ ( $n=3.574)$ of all the materials in this subdiscipline were published in the last ten years (2010-2020) and 39.7\% $(n=3.127)$ of them between 2000 and 2010. Although this number might seem quite high, actually I could identify only a few bibliometric analyses performed in the field of pediatric anesthesia ${ }^{(1,6-8)}$.

Brambrink et al. ${ }^{(1)}$ thought that there was a lack of compilation of literature on pediatric anesthesia. They identified publications, and respective journals regarding clinical practice in pediatric anesthesia, and assessed the academic output of some selected countries for a six-year period between 1993-1998. In their analysis, the scholars limited their search to articles, case reports, reviews, and editorials. Similar to the results of my study, they found that the highest number of materials was published in the journal of "Pediatric Anesthesia" followed by "Anesthesia \& Analgesia", "Canadian Journal of Anesthesia", "British Journal of Anesthesia" and "Anesthesiology". In my study, "Pediatric Anesthesia" was also on top of the list, followed by "Anesthesia and Analgesia", "British Journal of Anesthesia", "Anaesthesia" and "Anaesthesist". Brambrink et al. (1) also calculated the IF values of the journals that published articles on pediatric anesthesia. When I compared the top 5 journals of that study with the results of my research, I found out that 2018 IF values for all these journals were higher. This could reflect that the academic reputability of those journals has increased since 1998. Brambrink et al. ${ }^{(1)}$ found that the top five journals accounted for $46 \%$ of all published möaterial whereas in my study, they accounted for $79.5 \%$ of all published material. The reason for this increase could be the domination of the journal of "Pediatric Anesthesia" in the field of pediatric anesthesia in recent years.

In another study, Brambrink et al. ${ }^{(8)}$ analyzed the range of topics of published materials, as well as the types of them on pediatric anesthesia between 1993-1998. In my study, I did not investigate the spectrum of hot topics. However, such an analysis based on keywords or abstracts, could be used to identify both current trends and the historical hotspots of a specific discipline, as well ${ }^{(9,10)}$. It could also act as a guide for further scientific research ${ }^{(11)}$. Brambrink et al. ${ }^{(8)}$ found that $57.1 \%$ and $24.9 \%$ of the published materials were original articles and case reports, respectively, whereas, in my study articles, and letters constituted $53.4 \%$ and $23.5 \%$ of the published material, respectively.

In my study, the proportion of the number of articles to the total number of published materials from Turkey was similar to the global figure $158.3 \%$ and $53.2 \%$, respectively). For review articles Turkey's figure was statistically significantly lower than the global rate ( $0.3 \%$ vs $9.4 \%$ ). In Turkey, scholars do not get any credit from reviews for academic promotion. Therefore, scholars might not be willing to spend much effort to publish review articles.

According to my study, the average number of citations referenced from published materials from Turkey (15.2) was lower when compared with other countries (20.1). In another study which assessed the Turkish academic output in SCl and SCIE indexed journals in the field of anesthesiology, it was found that the mean number of citations from Turkish articles was at the very least among 22 countries ${ }^{(12)}$. These two results may indicate that published materials from Turkey in both anesthesiology and pediatric anesthesiology are not unique and interesting enough for other scholars. In fact, this result could be related to the intense clinical workload of Turkish physicians. According to the World Bank, the number of physicians per 1.000 people in Turkey was 1.85 whereas it was 2.79, 2.61, and 2.92 for the United Kingdom, the United States of America, and OECD countries, respectively ${ }^{(13)}$. These figures signify the greater workload placed on Turkish physicians. 
Scholars in Turkey in the field of medicine are also sometimes faced with permission issues to conduct academic researches. We note that some researches, for which we could not get permission from the ethics committee, could easily be conducted and published in other countries. This fact may have a negative impact on publishing original and unique articles which reduce the number of citations from Turkish articles.

In my study, the average number of authors for each published material from Turkey and other countries were 4.5 and 3.82 respectively. Publishing articles with multiple authors is a common trend. The rate of published materials from Turkey with 3 or more authors $(83.7 \%)$ was statistically significantly higher than that of other countries (64.7\%). Although the average number of authors per publication from Turkey was higher than the global average, when I looked at the academic productivity in the last 5 years, it appeared that the percentage of Turkish authors publishing articles in this field (18.1\%) seemed to be falling behind the global rate (23.5\%), though this difference was not statistically significant.

There are limitations in my study. I used Web of Science database to determine the country of origin of published materials. Similar searches in some other reputable databases such as Scopus, PubMed, or World Health Organization's databases could have given different results. Another limitation is the fact that I did the research based on the number of published materials, and did not consider the number of citations of these materials. A citation analysis could have given a different perspective. In my study, if the address line for any of the authors included "Turkey", I considered it to be a publication from Turkey. This is may be another limitation since some studies used the first author's country to determine the origin of published materials ${ }^{(14,15)}$ whereas other scholars assigned the country of publication according to the corresponding author ${ }^{(5,16)}$. However apparently a consensus has not been reached on determining the country of a published material.

Bibliometric analyses are conducted to determine the quantity and quality of published materials as well as the extent of the contributions of countries in a certain discipline, and are often used in different branches of medicine. The findings of this bibliometric analysis not only showed the level of contributions of Turkish authors to the field of pediatric anesthesia but also revealed potential areas of improvement for their future research. The study also revealed a list of journals that publish articles about pediatric anesthesia. Therefore, my colleagues who want to publish in this particular discipline could use this study as a guide for their future research. As the number of academic output and contributions of Turkish scholars in this field increases, similar periodically performed bibliometric analyses would be helpful to determine whether there has been an improvement in these areas.

\section{Acknowledgments}

The author would like to thank Mr. Robert Morris for his time and effort to go over the manuscript for spell check and use of English.

Ethics Committee Approval: Buca Seyfi Demirsoy Training and Research Hospital Non-Interventional Research Ethics Committee approval was obtained (27.01.2021/1-6).

Conflict of Interest: The author has no conflict of interest to declare.

Funding: This article did not receive any funding. Informed Consent: Since the study was retrospective, informed consent was not needed.

\section{REFERENCES}

1. Brambrink AM, Ehrler D, Dick WF. Publications on paediatric anaesthesia: a quantitative analysis of publication activity and international recognition. Br J Anaesth. 2000;85(4):55662.

https://doi.org/10.1093/bja/85.4.556

2. Doğan G, Karaca O. A bibliometric analysis of the field of anesthesia during 2009-2018. Brazilian J Anesthesiol. 2020;70(2):140-52. https://doi.org/10.1016/j.bjane.2020.04.013

3. Xie G, Zhang K, Wood C, Hoeft A, Liu J, Fang X. China's Contribution to Anesthesiology Research: A 10-Year Survey of the Literature. Anesth Analg. 2016;122(5):1640-5. https://doi.org/10.1213/ANE.0000000000001225

4. Tripathi RS, Blum JM, Papadimos TJ, Rosenberg AL. A bibliometric search of citation classics in anesthesiology. BMC Anesthesiol. 2011;11:24. 
https://doi.org/10.1186/1471-2253-11-24

5. Bould MD, Boet S, Riem N, Kasanda C, Sossou A, Bruppacher HR. National representation in the anaesthesia literature: a bibliometric analysis of highly cited anaesthesia journals. Anaesthesia. 2010;65(8):799-804. https://doi.org/10.1111/j.1365-2044.2010.06424.x

6. Alkhatip AAAMM, Younis M, Holmes C, Sallam A. Research Output from the Irish Paediatric Hospitals in the Field of Anaesthesia and Intensive Care Over 10 Years: A Bibliometric Analysis. Turkish J Anaesthesiol Reanim. 2020;48(3):223-8. https://doi.org/10.5152/TJAR.2019.06787

7. O'Leary JD, Crawford MW. Bibliographic characteristics of the research output of pediatric anesthesiologists in Canada. Can J Anesth. 2010;57(6):573-7. https://doi.org/10.1007/s12630-010-9292-6

8. Brambrink AM, Ehrler D, Dick WF. The topics of international publications on paediatric anaesthesia from 1993 to 1998. Paediatr Anaesth. 2000;10(5):549-55. https://doi.org/10.1046/j.1460-9592.2000.00565.x

9. Chen G, Xiao L. Selecting publication keywords for domain analysis in bibliometrics: A comparison of three methods. J Informetr. 2016;10(1):212-23. https://doi.org/10.1016/j.joi.2016.01.006

10. Tan J, Fu HZ, Ho YS. A bibliometric analysis of research on proteomics in Science Citation Index Expanded. Scientometrics. 2014;98(2):1473-90. https://doi.org/10.1007/s11192-013-1125-2
11. Liao H, Tang M, Luo L, Li C, Chiclana F, Zeng X-J. A Bibliometric Analysis and Visualization of Medical Big Data Research. Sustainability. 2018;10(1):166. https://doi.org/10.3390/su10010166

12. Özbilgin Ş, Hancı V. Turkish Publications in Science Citation Index and Citation Index-Expanded Indexed Journals in the Field of Anaesthesiology: A Bibliographic Analysis. Turkish J Anesthesiol Reanim. 2017;45(1):26-35. https://doi.org/10.5152/TJAR.2017.66587

13. World Bank. Physicians (per 1,000 people) | Data [Internet]. 2017 [retrieved 2020 Dec 6]. Available from: https://data. worldbank. org/indicator/SH.MED.PHYS. ZS?end $=2018 \&$ name_desc $=$ false\&start $=2018 \&$ view $=$ bar

14. Wang JO, Chen TJ, Kao S, Yeh TC, Chou LF, Ho ST. Scientific publications by anesthesia departments in East Asia. Scientometrics. 2012;92(1):135-43. https://doi.org/10.1007/s11192-012-0717-6

15. Yılmaz HO, Babazade R, Turan OA, Babazade B, Koyuncu O, Turan A. Scientific Publication Performance of Turkish Anaesthesia Clinics in High Impact Factor International Journals Between 2005 and 2014: A Bibliometric Analysis. Turkish J Anaesthesiol Reanim. 2017;45(1):16-25. https://doi.org/10.5152/TJAR.2016.16680

16. Pagel PS, Hudetz JA. A bibliometric analysis of geographic publication variations in the journal of cardiothoracic and vascular anesthesia from 1990 to 2011. J Cardiothorac Vasc Anesth. 2013;27(2):208-12. https://doi.org/10.1053/j.jvca.2012.08.022 